\title{
Adaptasi Tindakan Ekonomi Pelaku Sektor Pariwisata Pada Masa Pandemi Covid-19
}

\author{
Ni Wayan Ayu Santi ${ }^{*}$, Luh Indrayani ${ }^{2}$ \\ 1,2Universitas Pendidikan Ganesha, Singaraja - Indonesia
}

\section{A R T I C L E IN F O}

Article history:

Received November, 15 2021

Received in revised form November, 262021

Accepted December, 12021 Available online December, 252021

\section{Kata Kunci:}

Adaptasi, pelaku sektor

pariwisata, tindakan

ekonomi.

Keywords:

Adaptation, economic

action, tourism sector actors

\begin{abstract}
A B S T R A K
Pandemi Covid-19 yang berlangsung lebih dari setahun memberikan dampak kepada seluruh lapisan masyarakat, terutama pelaku sektor pariwisata di Provinsi Bali. Penelitian ini bertujuan untuk mengetahui adaptasi tindakan ekonomi pelaku sektor pariwisata pada masa pandemi Covid-19 di Banjar Lodsema, Desa Lodtunduh, Kecamatan Ubud, Kabupaten Gianyar, Provinsi Bali. Adapun metode penelitian ini yaitu penelitian kualitatif deskriptif. Subjek dari penelitian ini adalah pelaku sektor pariwisata di Banjar Lodsema sedangkan objeknya adalah adaptasi tindakan ekonomi yang dilakukan oleh pelaku sektor pariwisata pada masa pandemi Covid-19. Pengumpulkan data dilakukan dengan observasi dan wawancara. Data yang telah terkumpul dianalisis melalui tiga tahap, yaitu reduksi data, penyajian data, penarikan kesimpulan. Hasil penelitian ini menunjukkan bahwa terjadi adaptasi tindakan ekonomi pelaku sektor pariwisata di Banjar Lodsema, Desa Lodtunduh, Kecamatan Ubud, Kabupaten Gianyar, Provinsi Bali yang berupa (1) tindakan mengutamakan pemenuhan kebutuhan primer, (2) memaksimalkan usaha sektor pariwisata yang sudah dimiliki, (3) membuka usaha baru di bidang kuliner, (4) melakukan diversifikasi produk, (5) memaksimalkan usaha sampingan (secara online) yang telah dimiliki, (6) mencari penghasilan tambahan seperti menjadi buruh, (7) melakukan usaha lain di bidang pertanian dan peternakan, serta ada juga yang (8) melakukan trading forex.
\end{abstract}

\section{A B S T R A C T}

The Covid-19 pandemic that lasted more than a year had an impact on all levels of society, especially the tourism sector players in Bali Province. This study aims to determine the adaptation of the economic actions of tourism sector actors during the Covid-19 pandemic in Banjar Lodsema, Lodtunduh Village, Ubud District, Gianyar Regency, Bali Province. The research method is descriptive qualitative research. The subjects of this research are tourism sector actors in Banjar Lodsema while the object is the adaptation of economic actions taken by tourism sector actors during the Covid-19 pandemic. Data was collected by observation and interviews. The data that has been collected is analyzed through three stages, namely data reduction, data presentation, and conclusion drawing. The results of this study indicate that there is an adaptation of the economic actions of tourism sector actors in Banjar Lodsema, Lodtunduh Village, Ubud District, Gianyar Regency, Bali Province in the form of (1) actions prioritizing the fulfillment of primary needs, (2) maximizing the tourism sector business that is already owned, (3) opening a new business in the culinary field, (4) diversifying products, (5) maximizing the side business (online) that you already have, (6) looking for additional income such as being a laborer, (7) doing other businesses in agriculture and farms, and some (8) do forex trading.

Copyright (C Ekuitas: Jurnal Pendidikan Ekonomi. All rights reserved.

\footnotetext{
* Corresponding author.

E-mail : ayu.santi@undiksha.ac.id (Ni Wayan Ayu Santi)
} 


\section{Pendahuluan}

Covid-19 sampai saat ini masih menjadi kekhawatiran bagi masyarakat. Peneliti mengetahui hal tersebut dari hasil observasi pada salah satu banjar atau dusun yang merupakan bagian dari kecamatan Ubud, Gianyar, Bali. Meskipun vaksin tahap ke-2 telah diterima oleh masyarakat secara merata, namun pengendalian penyebaran Covid-19 masih menjadi kunci utama dalam proses pemulihan perekonomian di wilayah kecamatan Ubud. Ubud merupakan salah satu kecamatan yang merupakan destinasi wisata mancanegara maupun domestik yang sangat terkenal. Bahkan sebelum pandemi Covid-19 melanda, apabila kita melewati Ubud maka akan ramai oleh wisatawan baik mancanegara atau domestik yang berjalan kaki atau berlalu lalang di jalanan atau cafe atau pasar seni yang ada di Ubud dan sekitarnya. Namun berdasarkan hasil observasi peneliti, semenjak adanya pandemi Covid-19 wilayah Ubud menjadi daerah yang sepi wisatawan, sumber utama penghasilan masyarakat seketika menghilang. Masyarakat yang sebagian besar merupakan pelaku sektor pariwisata berusaha mencari alternatif agar tetap mendapatkan penghasilan seperti memberikan diskon pada produk barang atau jasa yang ditawarkan kepada wisatawan. Namun hal tersebut belum mampu mengembalikan keadaan seperti sebelum terjadinya pandemi Covid-19.

Pandemi Covid-19 yang masih berlangsung hingga saat ini membuat setiap lapisan masyarakat berdaptasi atau menyesuaikan diri. (Sumarni, 2020) menyatakan bahwa munculnya Covid-19 sudah membuat perubahan yang signifikan yang terjadi di masyarakat mulai dari segi sosial, budaya, ekonomi, pendidikan serta cara kita berpariwisata. Sebenarnya hal ini juga dipengaruhi oleh kebijakan yang diterapkan oleh pemerintah. Salah satu kebijakan yang sudah secara cepat diambil oleh pemerintah saat berwisata di masa pandemi Covid-19 yaitu melakukan prokes ketat saat melakukan wisata. Apabila kita memaknai lebih dalam dengan adanya pandemi Covid-19 tidak hanya menimbulkan dampak negatif berupa penurunan pendapatan masyarakat namun terdapat pula dampak positif dari pandemi Covid-19 ini. Pada masa pandemi ini dengan adanya physical distancing yang menyebabkan aktivitas kehidupan masyarakat terhambat untuk sementara, dengan harapan menurunkan jumlah yang terpapar virus. Akan tetapi justru hal ini menimbulkan dampak positif terhadap lingkungan hidup. Lingkungan hidup justru mendapatkan kesempatan untuk memperbaharui diri dengan adanya penurunan emisi karbon (Mangku et al., 2020). Oleh karena itu kita sebagai masyarakat harus beradaptasi pada masa pandemi ini. Beradaptasi dilakukan oleh setiap lapisan masyarakat dan masyarakat pun tetap melakukan aktivitas namun ada pengurangan interaksi sosial serta adanya kebiasaan baru menggunakan masker serta mulai hidup lebih bersih lagi. Begitu pula pada sektor pariwisata, sektor pariwisata juga melakukan adaptasi saat masa pandemi.

Adaptasi dalam Kamus Besar Bahasa Indonesia (KBBI) merupakan penyesuaian diri makhluk hidup agar dapat bertahan dalam kondisi lingkungan yang baru. Akibat dari adanya pandemi Covid-19 yang masih berlangsung sampai saat ini membuat masyarakat mau tidak mau harus melakukan adaptasi. Makna adaptasi tindakan dari segi pendidikan, pembelajaran, bekerja serta bertahan hidup pada masa pandemi perlu didalami agar kehidupan dapat berjalan sesuai dengan tujuan atau target yang diharapkan. Adaptasi menjadi salah satu objek penelitian yang menarik untuk diteliti saat ini karena adanya fenomena atau kejadian yang secara tiba-tiba telah mengubah segala aktivitas masyarakat tanpa adanya perencanaan terlebih dahulu. Sehingga diupayakan agar masyarakat bersedia menyesuaikan segala aktivitasnya dengan kebiasaan kehidupan baru guna mencegah penyebaran covid-19 lebih luas. Pandemi covid-19 menjadi suatu keadaan yang membuat masyarakat secara terpaksa atau mendadak melakukan adaptasi guna terhindar dari virus covid-19. Kegiatan berkumpul dengan banyak orang secara langsung mulai dihindari sehingga hal tersebut berdampak pada berbagai aktivitas masyarakat dalam mendapatkan penghasilan salah satunya pada sektor pariwisata seperti yang diungkapkan oleh (Arini et al., 2020) hal ini tentunya mengurangi mobilitas penduduk yang berdampak pada kinerja ekonomi suatu wilayah salah satunya sektor pariwisata. Sektor pariwisata di Bali merupakan salah satu sektor yang sedang diupayakan untuk diperhatikan sehingga mampu menarik wisatawan luar negeri, namun karena adanya pandemi covid-19 kunjungan wisatawan turun drastis. Seiring berjalannya waktu, sudah hampir lebih dari setahun pandemi ini berlangsung, masyarakat yang bekerja atau sumber penghasilannya di sektor pariwisata selalu berinovasi memberikan segala pelayanan prima dengan aman dan sehat sehingga terhindar dari virus covid-19. Begitu juga di Banjar Lodsema, Desa Lodtunduh, Kecamatan Ubud, Kabupaten Gianyar, Bali merupakan salah satu wilayah yang sumber utama penghasilan masyarakatnya adalah dari sektor pariwisata yang harus melakukan adaptasi selama masa pandemi covid-19. Adaptasi tersebut dilakukan para pelaku sektor pariwisata seperti melakukan adaptasi dalam tindakan ekonomi sehingga mendapat penghasilan untuk memenuhi kebutuhan atau untuk bertahan di masa pandemi.

Tindakan ekonomi merupakan suatu tindakan yang dilakukan oleh individu dengan pertimbangan tertentu yang didorong oleh usaha untuk memenuhi kebutuhan. Hal ini senada dengan pemaparan Damsar dalam (Hartika \& Purwaningsih, 2015) menyatakan bahwa tindakan akan berorientasi secara ekonomi sepanjang sesuai dengan makna subyektifnya yang difokuska pada pemenuhan terhadap suatu kebutuhan. 
Para pelaku sektor pariwisata pada masa pandemi Covid-19 melakukan adaptasi tindakan ekonomi sehingga mampu bertahan dalam situasi pandemi yang tidak diketahui kapan akan berakhir. Pelaku sektor pariwisata pada masa pandemi mengalami dampak secara langsung akibat adanya penurunan wisatawan yang berkunjung ke Provinsi Bali. Adanya Pandemi Covid-19 memberikan dampak yang cukup besar untuk Provinsi Bali. Seperti yang diketahui bahwa Bali merupakan salah satu destinasi wisata dunia, dengan adanya pandemi ini maka masyarakat di Bali harus mampu melakukan adaptasi. Selain itu dengan adanya kebijakan Pembatasan Sosial Berskala Besar (PSBB) serta Pemberlakuan Pembatasan Kegiatan Masyarakat (PPKM) pada sejumlah wilayah di Indonesia untuk menangani pandemi Covid-19 mengakibatkan penurunan minat masyarakat untuk ke luar rumah sehingga memberikan dampak pula pada sektor pariwisata. Hal ini berdasarkan laporan (Badan Pusat Statistik Provinsi Bali, 2021) bahwa pada triwulan III-2021 pemberlakuan pembatasan kegiatan masyarakat (PPKM) ditingkatkan levelnya menjadi PPKM darurat untuk wilayah Jawa-Bali yang diduga berdampak negatif terhadap aktivitas ekonomi di sejumlah kategori lapangan usaha. Masih berkaitan dengan sektor pariwisata, penurunan nilai tambah pada Kategori M,N (Jasa Perusahaan) pada triwulan III-2021 dibandingkan triwulan III-2020 utamanya bersumber dari menurunnya aktivitas agen dan biro perjalanan wisata. Ditutupnya tempat daya tarik wisata (DTW) selama PPKM darurat berdampak langsung pada penurunan jumlah tiket atau paket perjalanan yang terjual selama triwulan III-2021 dibandingkan dengan triwulan III-2020.

Sektor pariwisata memang menjadi mata pencaharian utama masyarakat di Bali, khususnya kecamatan Ubud, salah satunya di Banjar Lodsema yang merupakan perbatasan daerah Ubud dengan Sukawati. Banjar Lodsema merupakan salah satu banjara atau dusun yang unik karena terletak di daerah perbatasan antara kecamatan Ubud dengan Kecamatan Sukawati sehingga dari Banjar Lodsema mobilitas lebih cepat untuk ke daerah Ubud, Sukawati, Tabanan, Badung bahkan ke Denpasar. Oleh karena itu masyarakatnya juga menjadi pelaku sektor pariwisata yang bekerja di hotel, vila, pemandu wisatawan serta membuat kerajinan kayu. Hasil observasi peneliti pada awal pandemi, daerah ini masih bertahan melakukan aktivitas seperti biasa dengan menerapkan protokol kesehatan karena pemenuhan kebutuhan primer didapatkan dari bantuan pemerintah pusat, pemerintah daerah serta desa adat. Namun karena pandemi Covid-19 tidak kunjung selesai, serta wisatawan juga belum kunjung datang lagi ke Bali maka hal tersebut membuat para pelaku sektor pariwisata melakukan adaptasi tindakan ekonomi.

Berdasarkan latar belakang tersebut, peneliti tertarik melakukan penelitian di Banjar Lodsema, Desa Lodtunduh, Kecamatan Ubud, Kabupaten Gianyar, Bali yang sebagian besar penduduknya bergantung pada sektor pariwisata. Adanya pandemi covid-19 membuat para pelaku sektor pariwisata di Bali pesimis karena langsung kehilangan konsumen (wisatawan) secara dratis. Idealnya pelaku sektor pariwisata harus mampu melakukan adaptasi atau penyesuaian sesuai dengan keadaan atau situasi saat ini. Hasil observasi menunjukkan sebelum adanya pandemi Covid-19, masyarakat yang bekerja pada sektor pariwisata masih mengandalkan sumber pendapatan dari tempatnya bekerja saja. Namun setelah adanya pandemi Covid-19 terjadi adaptasi tindakan pelaku ekonomi sektor pariwisata di Banjar Lodsema sehingga penulis tertarik untuk mengetahui lebih lanjut. Tujuan dilakukan penelitian ini yaitu untuk mengetahui adaptasi tindakan ekonomi pelaku sektor pariwisata di Banjar Lodsema, Desa Lodtunduh, Kecamatan Ubud, Kabupaten Gianyar pada masa pandemi Covid-19.

\section{Metode}

Metode penelitian ini menggunakan metode kualitatif deskriptif. Metode kualitatif menurut (Creswell, 2016) merupakan penelitian yang mengeksplorasi dan memahami makna di sejumlah individu atau sekelompok orang yang berasal dari masalah sosial. Penelitian kualitatif secara umum dapat digunakan dalam penelitian yang berkaitan dengan kehidupan masyarakat, sejarah, tingkah laku, konsep atau fenomena, masalah sosial, dan lain-lain yang nanti dipaparkan secara deskriptif. Subjek dari penelitian ini adalah pelaku sektor pariwisata di Banjar Lodsema yang berada di Desa Lodtunduh, Kecamatan Ubud, Kabupaten Gianyar, Provinsi Bali sedangkan objeknya adalah adaptasi tindakan ekonomi yang dilakukan oleh pelaku sektor pariwisata pada masa pandemi Covid-19. Metode sampling dalam penelitian ini mengggunakan purposive sampling yang merupakan teknik pengambilan sampel sumber data dengan pertimbangan tertentu, contohnya informan tersebut dianggap paling tahu atau mengalami secara langsung terkait variabel dalam penelitian ini. Teknik yang digunakan dalam mengumpulkan data pada penelitian ini yaitu observasi dan wawancara. Data yang telah terkumpul dianalisis melalui tiga tahap, yaitu reduksi data, penyajian data, penarikan kesimpulan (Miles dan Huberman dalam (Sugiyono, 2016). Kegiatan dalam mereduksi data adalah kegiatan merangkum secara garis besar data yang sudah dipeoleh sehingga hasil penelitian menjadi jelas. Setelah itu dilakukan penyajian data. Data tersebut lalu dipaparkan ke dalam bentuk informasi sederhana terkait uraian tentang adaptasi tindakan ekonomi yang dilakukan oleh para 
pelaku sektor pariwisata pada masa pandemi covid-19. Terakhir adalah penarikan kesimpulan guna memudahkan mengetahui secara garis besar hasil penelitian.

\section{Hasil dan pembahasan}

Banjar Lodsema merupakan salah satu dusun di Desa Lodtunduh, Kecamatan Ubud, Kabupaten Gianyar, Provinsi Bali. Menjadi salah satu bagian dari kecamatan Ubud yang terletak di perbatasan Ubud dengan Sukawati membuat Banjar Lodsema menjadi salah satu banjar yang penduduknya bekerja di sektor pariwisata. Pekerjaan masyarakatnya antara lain ada yang bekerja di kantoran, bank, hotel, vila, yayasan budaya, kesenian (patung, keris, dan layang-layang) serta menjadi guide tour. Informan peneliti dalam penelitian ini yang memang betul merasakan dampak adanya pandemi Covid-19 memiliki latar belakang bekerja di hotel, bekerja di yayasan budaya, bekerja di vila, menjadi pemilik vila, menjadi guide tour pada suatu travel serta menjual barang kesenian yang harus memiliki kreativitas serta inovasi dalam menambah penghasilan mereka pada masa pandemi.

Sejak pandemi covid-19, salah satu usaha kesenian yaitu Mertasari Kite Shop hasil penjualannya ke wisatawan turun drastis hampir mendekati nol. Oleh karena itu Mertasari Kite Shop melakukan adaptasi tindakan ekonomi. Adaptasi tersebut dilakukan guna mempertahankan usaha tetap berjalan di masa pandemi. Adapun pernyataan dari I Wayan Suteja mengatakan bahwa:

"Selama pandemi penjualan ke masyarakat domestik agak meningkat selama musim layangan dari bulan Mei dampai September serta juga penjualan ke pulau jawa lumayan bagus karena masyarakat di jawa sangat menyukai layang-layang dari Bali."

Berdasarkan hasil wawancara dan observasi, peneliti menemukan bahwa terjadi adaptasi tindakan ekonomi pelaku sektor pariwisata Banjar Lodsema. Menurut (Hamzah et al., 2021) adaptasi adalah cara makhluk hidup mengatasi tekanan terhadap perubahan lingkungan yang relatif kurang menguntungkan. Adaptasi itu dilakukan agar mampu memenuhi kebutuhan sehari-hari serta memikirkan jangka panjang ke depannya apabila pandemi Covid-19 tidak tau kapan berakhirnya. Oleh karena itu, pelaku sektor pariwisata tidak hanya mengandalkan sumber penghasilan dari pariwisata saja.

Adaptasi tindakan ekonomi pelaku sektor pariwisata di Banjar Lodsema antara lain:

a. Mengutamakan pemenuhan kebutuhan primer

Pada masa pandemi Covid-19, pelaku sektor pariwisata tetap bekerja atau melakukan kegiatan seperti sebelum terjadinya pandemi Covid-19 walaupun ada yang bekerja hanya setengah hari atau dalam satu minggu bekerja hanya dua atau tiga kali, adaptasi tindakan ekonomi yang dilakukan yakni tetap mengutamakan pemenuhan kebutuhan primer dari penghasilan yang diperoleh walaupun ada pemotongan penghasilan dari perusahaan. Jadi para pelaku sektor pariwisata mengutamakan pemenuhan kebutuhan primer seperti untuk membeli sembilan bahan pokok (sembako) antara lain beras, minyak goreng, gula pasir, daging ayam, telur, susu, bawang merah atau putih, bahan untuk memasak serta garam beryodium.

b. Memaksimalkan usaha sektor pariwisata yang sudah dimiliki

Adaptasi tindakan ekonomi ini, bagi penulis sering dikenal dengan istilah intensifikasi. Intesifikasi merupakan salah satu cara untuk meningkatkan produksi usaha dengan memaksimalkan faktor produksi yang sudah ada. Hal ini juga ditegaskan kembali pada (Hamzah et al., 2021) yang menyebutkan bahwa strategi adaptasi intensifikasi merupakan upaya yang dilakukan dalam menghadapi permasalahan yang menghambat terhadap aktivitas produksi. Jadi, pelaku sektor pariwisata yang memiliki vila melakukan perbaikan atau renovasi atau peningkatkan kemampuan sumber daya manusia yang dimiliki sehingga para karyawanya memiliki kemampuan untuk memberikan pelayanan jasa prima kepada wisatawan.

c. Membuka usaha baru

Pandemi Covid-19 yang sudah lebih dari setahun ini memaksa pelaku sektor pariwisata dari Banjar Lodsema untuk melakukan adaptasi tindakan ekonomi seperti membuka usaha baru. Usaha baru yang dibuka ini ada di bidang kuliner berupa usaha makanan dan minuman khas Bali serta cafetaria yang target konsumennya masyarakat Banjar Lodsema dan sekitarnya. Berdasarkan hasil wawancara kepada responden menyatakan bahwa hasil penjualan dari usaha yang baru dibuka saat pandemi tersebut ternyata cukup menjanjikan karena target konsumennya merupakan masyarakat yang berdomisili di daerah Banjar Lodsema dan sekitarnya. Hal ini mmebuat para pelaku sektor pariwisata mendapatkan penghasilan tambahan dari usaha barunya ini guna memenuhi kebutuhan. 
d. Melakukan diversifikasi produk

Diversifikasi produk merupakan penganekaragaman hasil produksi dalam suatu usaha. Berdasarkan hasil penelitian, pelaku sektor pariwisata dari Banjar Lodsema ada yang melakukan diversifikasi produk pada masa pandemi Covid-19. Pada awalnya hanya menjual layang-layang untuk para wisatawan namun sejak pandemi mulai memproduksi kain atau perlengkapan upacara agama hindu yang dijual untuk masyarakat setempat dan sekitarnya. Selain itu sudah juga dilakukan strategi pemasaran melalui sosial media untuk menjangkau target pemasaran yang lebih luas. Hal ini senada dengan hasil penelitian yang dilakukan oleh (Mangku et al., 2020) yang menyatakan bahwa penerapan diversifikasi produk pada usaha Kuswini katering tergolong berhasil karena dapat mendongkrak penjualan dan meminimalisir dampak dari pandemi Covid-19 itu sendiri.

e. Memaksimalkan usaha sampingan (secara online) yang telah dimiliki

Adaptasi pelaku sektor pariwisata lainnya dalam hal ini dilakukan dengan cara memaksimalkan usaha sampingan yang telah dimiliki seperti menjual produk pakaian secara online serta penyedia jasa membuat kartu digital. Pemaksimalan usaha sampingan itu dilakukan dengan melakukan promosi via online dan offline melalui sanak saudara. Berdasarkan hasil wawancara kepada salah satu responden menyatakan bahwa usaha sampingan ini juga berkembang sebelum maupun saat adanya pandemi sehingga penyesuaian atau adaptasi tindakan ekonomi yang dilakukan terkait konsistensi dalam melakukan pemostingan di social media sehingga menjangkau target pasar yang lebih luas.

f. Mencari penghasilan tambahan seperti menjadi buruh

Adaptasi tindakan ekonomi lainnya seperti mencari penghasilan tambahan. Pelaku sektor pariwisata lainnya yang tidak memiliki modal atau keahlian tertentu berusaha mencari penghasilan tambahan dengan menjadi buruh. Hanya saja ini biasanya dilakukan saat ada proyek padat karya yang didanai oleh dana desa atau menjadi buruh bangunan part time karena masih bekerja di tempat utama namun karena pandemi jam kerja dikurangi sehingga sisa waktu dimanfaatkan untuk bekerja menjadi buruh. Berdasarkan hasil wawancara penghasilan menjadi buruh ini diberi upah kisaran Rp60.000,00 sampai Rp100.000,00 disesuaikan dengan jam kerja.

g. Melakukan usaha lain di bidang pertanian dan peternakan

Selain itu para pelaku sektor pariwisata pada masa pandemi melakukan pemanfaatan halaman rumah untuk menanam kebutuhan primer seperti sayur-sayuran sehingga bisa mengurangi pengeluaran uang untuk membeli sayuran dan ada pula yang memulai usaha menernak bebek, ayam dan babi selama masa pandemi untuk menambah penghasilan. Kegiatan ini masih relevan dilakukan karena Banjar Lodsema masih merupakan daerah pedesaan.

h. Melakukan trading forex

Para pelaku sektor pariwisata yang memiliki dana dan pengetahuan lebih banyak dari yang lainnya mencoba melakukan hal baru di luar sektor pariwisata, salah satunya kegiatan yang bisa dilakukan dimana saja dan kapan saja dengan risiko dan keuntungan tinggi yaitu mencoba trading forex. Trading forex merupakan kegiatan jual beli mata uang eletronik. Hal ini juga dilakukan sebagai salah satu adaptasi tindakan ekonomi pelaku sektor pariwisata dari Banjar Lodsema. Berdasarkan hasil wawancara menyebutkan bahwa pelaku sektor pariwisata ini belajar tentang trading forex dari komunitas yang diikutinya serta sambil mengisi waktu luang dengan harapan memberikan penghasilan tambahan di masa pandemi.

Berdasarkan pemaparan di atas, terjadi adaptasi tindakan ekonomi yang dilakukan oleh para pelaku sektor pariwisata di Banjar Lodsema, Desa Lodtunduh, Kecamatan Ubud, Kabupaten Gianyar, Bali. Hal ini juga diungkapkan oleh Persada (2020) menyatakan bahwa dalam menghadapi masa darurat pandemi, adaptasi yang dilakukan yaitu bertahan bagi pelaku pariwisata, sebagaimana sektor lainnya. Para pelaku sektor pariwisata pindah ke industri kreatif yang menjadi kebutuhan dasar, seperti kuliner dan fashion. Pada tahapan kedua yaitu persiapan menuju new normal, pada tahap ini pelaku pariwisata bersama masyarakat bersama-sama menyiapkan produk pariwisata sesuai dengan kebiasaan baru. Pada tahap ini membangun kembali kepercayaan wisatawan melalui re-branding. Pada tahap new normal, sektor pariwisata diharapkan sudah memiliki paradigma pengembangan adaptif dan inovatif dalam kesiapan menghadapi kebiasaan baru tersebut. Melalui tahapan tersebut, berbagai komunitas di masyarakat sebagai modal sosial telah dan akan terus membangun jaringan kerjasama, komitmen bersama, kepercayaan hingga pemberdayaan dengan tujuan peningkatan kreativitas hingga tercipta inovasi produk pariwisata era new normal. 
Sampai saat ini kegiatan baru tersebut terus dilakukan oleh pelaku sektor pariwisata selain mereka tetap memberikan berbagi promosi. Karena memang tidak mudah mengembalikan kepercayaan keselamatan masyarakat untuk berwisata pada masa pandemi. Seperti yang diungkapkan oleh (Suprihatin et al., 2020) mengembalikan lagi kepercayaan wisatawan sangat dibutuhkan, ditengah kecemasan dan kebutuhan untuk berwisata. Selain itu menurut hasil penelitian yang dilakukan oleh (Kadarisman, 2021) pada masa pandemi Covid-19 tempat wisata diupayakan beradaptasi dengan kebijakan yang telah dibuat dalam menghadapi pandemi Covid-19. Pengembangan pariwisata lokal dalam masa pandemi diperlukan agar sektor pariwisata tetap berjalan dan ekonomi dapat terbangun kembali. Pengembangan pariwisata lokal dengan protokol kesehatan akan menjadi kewajiban bagi pemerintah dan pengelola wisata serta merupakan suatu kewajiban yang harus diikuti oleh pengelola, wisatawan maupun masyarakat di sekitar tempat wisata.

Berdasarkan pemaparan di atas adaptasi tindakan ekonomi yang dilakukan pelaku sektor pariwisata Banjar Lodsema secara ringkas yaitu mengutamakan pemenuhan kebutuhan primer, memaksimalkan usaha sektor pariwisata yang sudah dimiliki, membuka usaha baru di bidang kuliner, melakukan diversifikasi produk, memaksimalkan usaha sampingan (secara online) yang telah dimiliki, mencari penghasilan tambahan seperti menjadi buruh, melakukan usaha lainnya di bidang pertanian dan peternakan, serta ada juga yang melakukan trading forex. Hasil penelitian tersebut didukung oleh hasil penelitian yang dilakukan oleh Hamzah (2021) yang menyatakan bahwa adapun strategi adaptasi yang dilakukan oleh masyarakat nelayan dalam beberapa bentuk, antara lain diversifikasi, intensifikasi, pemanfaatan jaringan sosial, mobilisasi anggota keluarga dan perubahan daerah penangkapan ikan. Hal ini juga diperkuat dari paparan (Hoque et al 2020) bahwa virus Corona menimbulkan dampak jangka panjang bagi industri pariwisata. Oleh karena itu perlu membuat perubahan strategis yang dapat membantu bisnis untuk bertahan dari pandemi (Krishna, 2020)

\section{Simpulan dan saran}

Covid-19 merupakan virus yang membuat terjadinya perubahan di setiap segmen kehidupan secara paksa karena interaksi sosial secara langsung masyarakat menjadi terbatas. Pada masa pandemi Covid-19 setiap lapisan masyarakat diupayakan untuk bisa beradaptasi. Begitupula yang terjadi pada pelaku sektor pariwisata Banjar Lodsema yang merupakan bagian dari kecamatan Ubud berusaha melakukan adaptasi tindakan ekonomi guna mempertahan kehidupan pada masa pandemi apalagi dengan berbagai kebijakan PSBB dan PPKM.

Adapun adaptasi tindakan ekonomi yang dilakukan pelaku sektor pariwisata Banjar Lodsema yaitu mengutamakan pemenuhan kebutuhan primer, memaksimalkan usaha sektor pariwisata yang sudah dimiliki, membuka usaha baru di bidang kuliner, melakukan diversifikasi produk, memaksimalkan usaha sampingan (secara online) yang telah dimiliki, mencari penghasilan tambahan seperti menjadi buruh, melakukan usaha lain di bidang pertanian dan peternakan, serta ada juga yang melakukan trading forex. Berbagai upaya adaptasi tindakan ekonomi telah dilakukan oleh pelaku sektor pariwisata di Banjar Lodsema, mereka berpikiran positif bahwa optimis pariwisata akan pulih kembali serta selalu memikirkan cara menambah penghasilan dan menyesuaikan diri terhadap berbagai kebijakan pemerintah sehingga kebutuhan tetap dapat terpenuhi diimbangi dengan perekonomian bisa stabil kembali.

Saran yang dapat diberikan kepada pelaku sektor pariwisata yakni tetap konsisten mengoptimalkan tindakan ekonomi hasil adaptasi adanya pandemi Covid-19 seperti bekerja sepenuh hati dengan menerapkan protokol kesehatan, melakukan promosi usaha barunya sehingga mampu menjadi penghasilan utama selain mendapatkan penghasilan dari sektor pariwisata. Selain itu saran untuk peneliti selanjutnya yakni dapat juga melakukan penelitian sejenis namun menggunakan lokasi atau subjek yang berbeda sehingga mampu menambah wawasan pengetahuan para pembaca terkait adaptasi tindakan ekonomi yang dilakukan oleh masyarakat yang bekerja pada sektor lainnya pada masa pandemi.

\section{Daftar Rujukan}

Arini, I. A. ., Paramitha, I. B. ., \& Triana, K. . (2020). Ekspektasi, Realisasi, dan Negosiasi Tourism Reborn di Masa Pandemi dalam Pariwisata Bali. 1(2), 101-112.

Badan Pusat Statistik Provinsi Bali. (2021). Pertumbuhan Ekonomi Bali Triwulan I-2021. Bps.Go.Id, 27, 116. https://jakarta.bps.go.id/pressrelease/2019/11/01/375/tingkat-penghunian-kamar--tpk-hotel--berbintang-dki-jakarta-pada-bulan-september-2019-mencapai-58-97-persen.html

Creswell, J. W. (2016). Research design: pendelatakan Metode kualitatif, kuantitatif dan Campuran. Pustaka pelajar.

Hamzah, A., Sutrawan Nurdin Program Studi Ilmu Perikanan, H., Sultan Ageng Tirtayasa Jl Raya Jakarta, U. 
K., \& Serang, K. (2021). PERIKANAN NUSANTARA KARANGANTU. Jurnal Akuatika Indonesia, 6(1).

Hartika, S., \& Purwaningsih, E. (2015). Analisis tindakan dan motif ekonomi masyarakat dalam upaya peningkatan jenjang pendidikan anak di desa tebas sungai. Jurnal Untan, 1-10. http://jurnal.untan.ac.id

Hoque, A., Shikha, F.A., Hasanat, M.W., Arif, I., Hamid, A. B. A. (2020). The Effect of Coronavirus (Covid-19) in the Tourism Industry in China. Asian Journal of Multidisciplinary Studies., 3(1).

Kadarisman, A. (2021). Government public relations dalam pengembangan pariwisata masa pandemi COVID-19 di Geopark Ciletuh. PRofesi Humas, 5(2), 270-290.

Krishna, S. V. (2020). Changing Business Strategies During Pandemic Covid-19. IOSR Journal of Buseness and Management (IOSR-JBM), 22(5 Ser. VII), 33-36.

Mangku, H. B., Suharjo, R. P., Bakhri, S., Rinderiyana, Y., Sunardi, |, Rochana, E., Lin, K., Gunawan, A., Tantowi, |, Christian, A. |, Cahyo, H., Finka, S., Adiwisastra, S., Ramadhoni, I., Rilda, |, Athik, T. |, Ummah, H., Amala, A., Barnawi, E., ... Zailani, J. (2020). Covid19 Disrupsi \&.

Sugiyono. (2016). Metode Penelitian Kuantitatif, Kualitatif, dan R \& D. Alfabeta.

Sumarni. (2020). Implementasi Kebijakan Kementerian Pariwisata dan Ekonomi Kreatif dalam Menghadapi Adabtasi Kebiasaan Baru di bidang Pariwisata Study Kasus di Kabupaten Gunungkidul. 2020(October), 14-15.

Suprihatin, W., Pengembangan, B., Daya, S., Daerah, M., Nusa, P., \& Barat, T. (2020). Analisis Perilaku Konsumen Wisatawan Era Pandemi Covid-19 (Studi Kasus Pariwisata di Nusa Tenggara Barat). 